\title{
Pengaruh Pemberian Vitamin C Terhadap Kualitas Spermatozoa Yang Terpapar Asap Rokok
}

\author{
Frenky D. Awuy, ${ }^{1}$ Diana S. Purwanto, ${ }^{2}$ Yanti M. Mewo ${ }^{2}$
}

\author{
${ }^{1}$ Program Studi Pendidikan Dokter Fakultas Kedokteran Universitas Sam Ratulangi, \\ Manado, Sulawesi Utara, Indonesia \\ ${ }^{2}$ Bagian Biokimia Fakultas Kedokteran Universitas Sam Ratulangi, Manado, Sulawesi \\ Utara, Indonesia \\ Email: frenkyawuy24@gmail.com
}

\begin{abstract}
Cigarettes can cause oxidative stress that may cause various health problems such as the decrease of spermatozoa quality. The disturbed state of spermatozoa results in a decrease quality of the spermatozoa which may effect fertility. Vitamin $\mathrm{C}$ is an antioxidant which is believed to affect improving the quality of spermatozoa. This study aimed to determine the effect of vitamin $\mathrm{C}$ on the quality of spermatoza exposed to cigarette smoke. This research was conducted by literature review using three databases, namely Google Scholar, Pubmed, and ClinicalKey. After being selected based on inclusion and exclusion criteria, there were 10 articles research for assessment. The results show that the decrease in spermatozoa concentration is due to the nicotine contained in cigarette smoke. By giving vitamin $\mathrm{C}$, it can reduce oxidative stress which can cause lipid peroxidation, and then reduce the decrease in spermatozoa concentration. There is also an improvement in spermatozoa motility and morphology after vitamin $\mathrm{C}$ administration. Vitamin $\mathrm{C}$ as an antioxidant plays a role in fighting free radicals, so that the spermatozoa cell membrane remains protected. In conclusion, consumption of vitamin $\mathrm{C}$ shows an effect to improve the quality of spermatozoa exposed to cigarette smoke, including increasing/improving the concentration, morphology, and motility of spermatozoa.
\end{abstract}

Keywords: vitamin C, spermatozoa, smoker

\begin{abstract}
Abstrak: Rokok menyebabkan terjadinya stres oksidatif yang dapat mengakibatkan berbagai gangguan kesehatan seperti penurunan kualitas spermatozoa. Keadaan spermatozoa yang terganggu mengakibatkan penurunan kualitas spermatozoa sehingga akan memengaruhi kesuburan. Vitamin C merupakan antioksidan yang dipercaya dapat memengaruhi peningkatan kualitas spermatozoa. Penelitian ini bertujuan untuk mengetahui pengaruh pemberian vitamin C terhadap kualitas spermatoza yang terpapar asap rokok. Penelitian ini berbentuk literature review dengan pencarian data menggunakan tiga database yaitu Google Scholar, Pubmed, dan ClinicalKey. Setelah diseleksi berdasarkan kriteria inklusi dan eksklusi, didapatkan 10 artikel untuk dilakukan penilaian. Hasil penelitian menunjukkan bahwa penurunan konsentrasi spermatozoa disebabkan oleh kandungan nikotin dalam asap rokok. Pemberian vitamin $\mathrm{C}$ dapat menurunkan stres oksidatif yang dapat menyebabkan terjadinya peroksidasi lipid, kemudian menekan penurunan konsentrasi spermatozoa. Terdapat juga perbaikan motilitas dan morfologi spermatozoa setelah pemberian vitamin C. Vitamin C sebagai antioksidan berfungsi untuk menanggulangi radikal bebas, sehingga membran sel spermatozoa akan tetap terlindungi. Sebagai simpulan, pemberian vitamin $\mathrm{C}$ menunjukkan adanya pengaruh untuk meningkatkan kualitas spermatozoa yang terpapar asap rokok, meliputi peningkatan/perbaikan konsentrasi, morfologi, dan motilitas spermatozoa.
\end{abstract}

Kata kunci: vitamin C, spermatozoa, asap rokok 


\section{PENDAHULUAN}

Merokok dapat menyebabkan gangguan pada kesehatan. Berbagai penyakit dapat timbul karena merokok. Kebiasaan merokok dapat merugikan bagi perokok dan juga orang di sekitarnya. ${ }^{1}$ Pada saat ini, Indonesia menempati urutan ketiga jumlah masyarakat yang merokok setelah China dan India. Prevalensi merokok di Indonesia semakin meningkat jumlahnya yaitu $27 \%$ pada tahun 1995 , menjadi $36,3 \%$ pada tahun 2013. Berdasarkan jenis kelamin, prevalensi merokok pada pria lebih tinggi dibandingkan wanita. ${ }^{2}$

Rokok menyebabkan terjadinya stress oksidatif yang dapat mengakibatkan berbagai gangguan kesehatan seperti, kanker paru-paru, kanker esofagus, kanker laring, aterosklerosis, gangguan kehamilan, dan juga penurunan kualitas spermatozoa. ${ }^{3}$ Stres oksidatif merupakan kondisi ketidakseimbangan antara radikal bebas dengan antioksidan. Kondisi seperti ini akan meningkatkan jumlah Reactive Oxygen Species (ROS). ROS adalah agen pengoksidasi sangat reaktif yang termasuk pada kelas radikal bebas, dan juga merupakan kelompok molekul kimia yang sangat reaktif dengan satu atau lebih elektron tidak berpasangan yang dapat secara oksidatif memodifikasi biomolekul yang dihadapi. ${ }^{4}$

Penurunan kualitas spermatozoa diakibatkan oleh peningkatan kadar Reactive Oxygen Species (ROS) dan penurunan antioksidan pada sperma yang mengganggu spermatogenesis. Radikal bebas yang berasal dari asap rokok dapat menyebabkan kerusakan pada deoxyribonucleic acid (DNA) dan apoptosis sel spermatozoa. ${ }^{5}$ Merokok memberikan dampak negatif pada kualitas spermatozoa seperti penurunan jumlah spermatozoa, perubahan motilitas spermatozoa, dan perubahan morfologi spermatozoa yang diikuti oleh peningkatan ROS dalam sperma. $^{6}$

Oleh karena itu dibutuhkan sistem pembersih berupa antioksidan yang dapat menetralkan efek dari ROS. ${ }^{7}$ Ketersediaan antioksidan di dalam tubuh harus cukup seimbang dengan radikal bebas dan kadang perlu ditingkatkan dengan bantuan sistem antioksidan eksogen salah satunya adalah vitamin $\mathrm{C}^{8}{ }^{8}$

Vitamin $\mathrm{C}$ merupakan salah satu jenis vitamin yang sering ditemui dan dikonsumsi dikalangan masyarakat, serta dapat ditemukan dalam berbagai jenis bahan makanan seperti buah-buahan berupa jambu, jeruk, nanas, tomat dan berupa sayur-sayuran dan suplemen. Vitamin ini merupakan suatu antioksidan non-enzimatis yang mempunyai sifat polaritas yang tinggi karena banyak mengandung gugus hidroksil sehingga mudah larut dalam air, dan terletak pada cairan ekstraseluler. Vitamin C memiliki kemampuan untuk melawan dan menetralisir radikal bebas dari segi kerusakan DNA yang diinduksi maupun akibat produksi yang berlebihan. ${ }^{9}$

Berdasarkan penelitian yang dilakukan oleh Batubara dkk pada tahun 2013, paparan asap rokok yang dilakukan pada mencit jantan didapatkan bahwa semakin banyak jumlah paparan asap rokok yang diberikan semakin menurunkan kualitas spermatozoa mencit yang meliputi penurunan konsentrasi dan motilitas serta perubahan morfologi spermatozoa. Efek negatif ini diduga disebabkan oleh zat kimia dari asap rokok yang dapat menimbulkan peningkatan produksi radikal bebas sehingga mencetuskan stres oksidatif. ${ }^{10}$

Berdasarkan uraian di atas, penurunan kualitas spermatozoa merupakan suatu kondisi yang kurang disadari oleh masyarakat, terlebih khusus pada kaum pria. Berbagai macam cara telah dilakukan untuk mengatasi masalah ini termasuk melalui pemberian vitamin $\mathrm{C}$ atau sumber makanan yang mengandung vitamin $\mathrm{C}$ yang diketahui memiliki antioksidan yang tinggi dan dipercaya bisa memperbaiki kualitas spermatozoa. Oleh karena itu, pada penelitian ini peneliti tertarik untuk meneliti lebih lanjut tentang pengaruh pemberian vitamin $\mathrm{C}$ atau sumber makanan yang mengandung vitamin $\mathrm{C}$ terhadap kualitas spermatozoa yang terpapar asap rokok. 


\section{METODE PENELITIAN}

Penelitian ini menggunakan rancangan metode literature review dengan mengidentifikasi, mengevaluasi, dan menginterpretasi terhadap semua hasil penelitian tertentu terkait topik yang menjadi perhatian. Dilakukan pencarian data berupa jurnal penelitian dengan menggunakan tiga database yaitu Google Scholar, PubMed, dan ClinicalKey. Kata kunci yang digunakan dalam pencarian yaitu Vitamin C DAN spermatozoa DAN asap rokok dan vitamin $C A N D$ spermatozoa AND smoker. Literature yang direview dalam bahasa Inggris dan Indonesia.

\section{HASIL PENELITIAN}

Berdasarkan hasil pencarian literature melalui publikasi di tiga database didapatkan artikel sebanyak 6.758 artikel. kemudian dilakukan skrining berdasarkan judul yang sesuai dengan tema literature review didapatkan 85 artikel. Selanjutnya didapatkan 35 artikel fulltext dilakukan penilaian kelayakan berdasarkan kriteria ekslusi dan inklusi dan didapatkan 10 $\operatorname{artikel}^{7,11-19}$ yang memenuhi kriteria inklusi, terdiri dari enam penelitian experimental dengan post test only control group design, tiga penelitian eksperimental dengan completely randomized design, dan satu penelitian eksperimental dengan single blinded clinical trial. Literatur yang dipakai melibatkan penelitian pada hewan coba dan manusia perokok. (Tabel 1).

\section{BAHASAN}

Hasil penelitian yang direview secara umum membahas bahwa paparan asap rokok dapat menurunkan kualitas spermatozoa. Asap rokok mengandung senyawa kimia beracun berupa nikotin, tar, dan karbonmonoksida. Bahan kimia tersebut berdampak pada ketidakseimbangan antara ROS dan antioksidan sehingga membuat efek yang tidak baik terhadap kualitas spermatozoa, meliputi konsentrasi, motilitas, dan morfologi spermatozoa. $^{20}$

Konsentrasi mengalami penurunan disebabkan oleh nikotin yang terkandung dalam asap rokok. Nikotin dapat menurunkan jumlah atau konsentrasi spermatozoa dengan mengganggu proses respirasi seluler dalam mitokondria, yang berujung pada pembentukan ROS, seperti superoksida anion dan hidrogen peroksida yang selanjutnya meningkatkan oksidative stress. Kerusakan oksidatif mengakibatkan terjadinya proses apoptosis sel yang berujung pada penurunan jumlah spermatozoa., ${ }^{9,16}$

Adapun penurunan motilitas spermatozoa, diduga disebabkan juga oleh nikotin yang membentuk radikal bebas sehingga akan merusak membran tipis sitoplasma di bagian kepala. ${ }^{13}$ Membran plasma ini kaya akan polysaturated fatty acids (PUFAs) yang merupakan salah satu target ROS dalam peroksidasi lipid. Kerusakan pada membran plasma ini mengakibatkan terjadi kerusakan struktur organel, gangguan transduksi sinyal, sistem transportasi molekul, regulasi metabolit, dan pembentukan ATP. ${ }^{9,20}$ Hal ini menyebabkan terjadinya penurunan viabilitas dan penurunan motilitas atau gerakan spermatozoa sehingga lebih sulit untuk membuahi sel telur. ${ }^{9,14}$

Sementara itu, radikal bebas yang terbentuk juga meningkatkan kerusakan morfologi spermatozoa karena reaksi oksidatif yang ditimbulkan menyebabkan mutasi pada DNA mitokondria. ${ }^{9}$ Pada pemberian ekstrak tembakau pada mencit terbukti terjadi abnormalitas pada setiap bagian mulai dari kepala, leher, badan sampai ekor dari spermatozoa. ${ }^{14}$

Reactive Oxygen Species (ROS) yang dikenal juga sebagai radikal bebas, adalah molekul yang pada lapisan elektron terluarnya tidak mempunyai elektron berpasangan sehingga akan selalu berusaha mengambil elektron dari molekul atau senyawa lain di sekitarnya. ROS bersifat sangat reaktif yang terdiri atas kelompok radikal misalnya ion superoksida $\left(\mathrm{O}_{2}{ }^{-}\right)$, ion hidroksil $\left(\mathrm{OH}^{-}\right)$, dan peroksil $\left(\mathrm{RO}_{2}\right)$, dan kelompok non radikal seperti hidrogen peroksida $\left(\mathrm{H}_{2} \mathrm{O}_{2}\right)$ dan organic peroxides. ${ }^{20}$ 


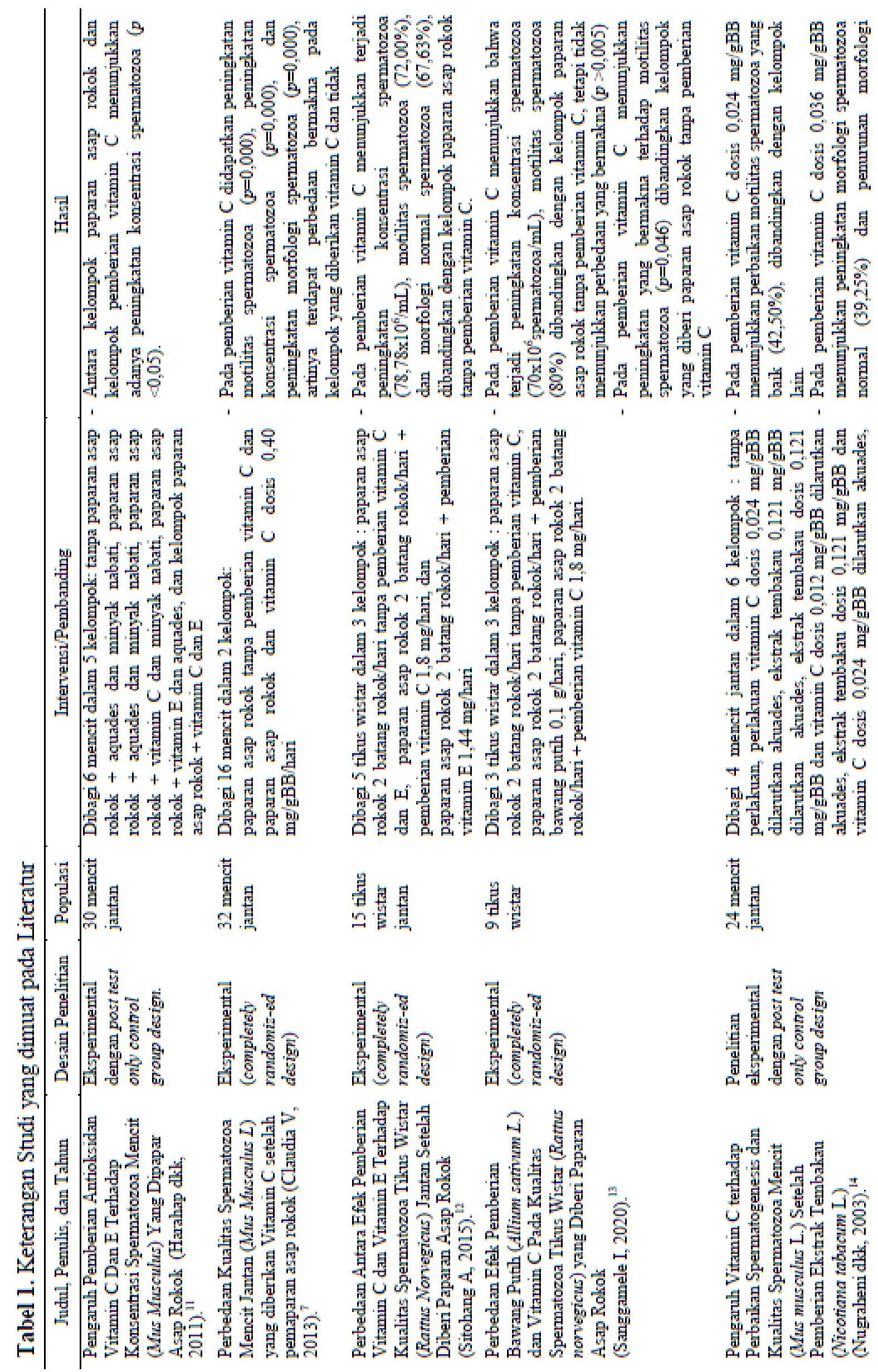




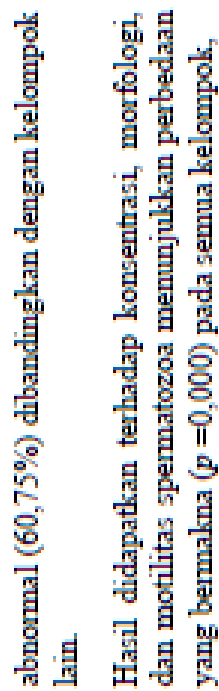

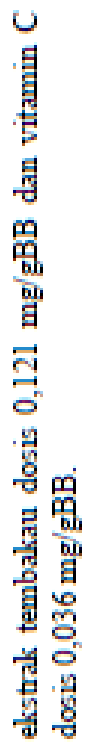

年 +5

령영

-

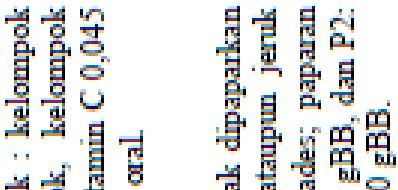

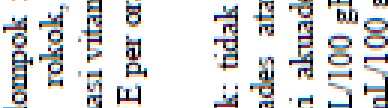

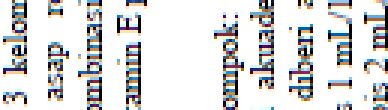

穿 + 曾首

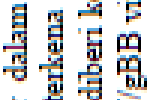

青学总

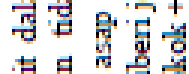

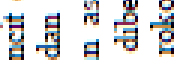

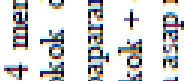

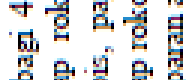

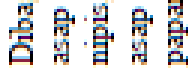

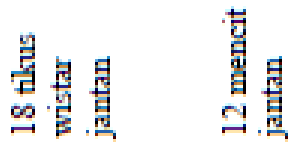

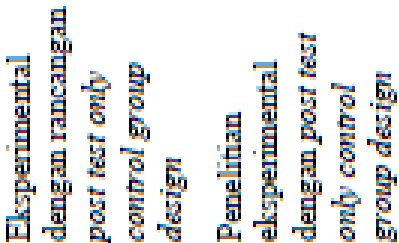

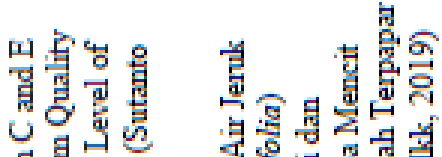

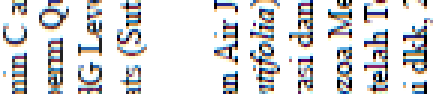

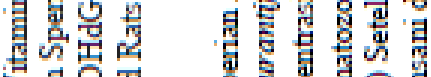

5

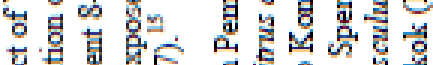

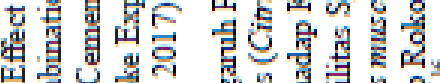

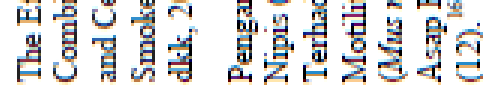

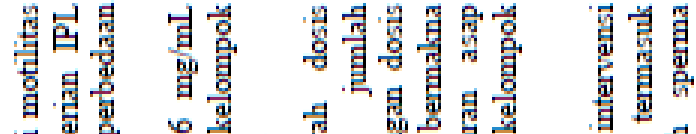

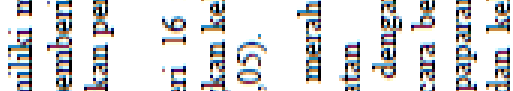

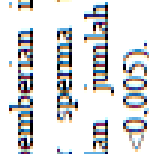

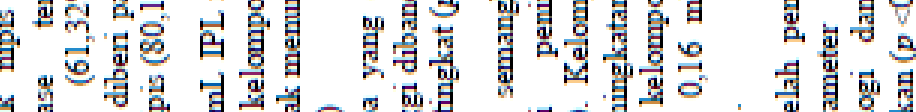

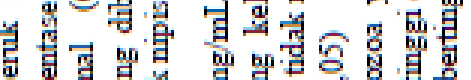

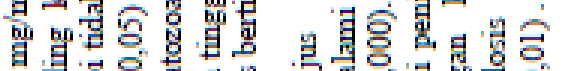

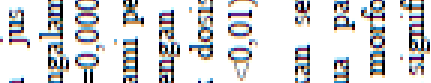

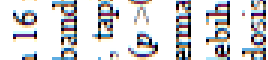

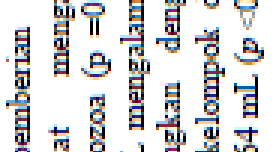

要要

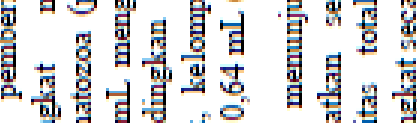

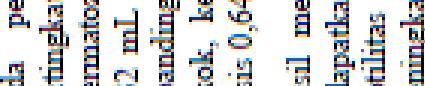

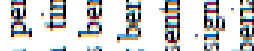

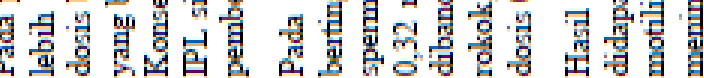

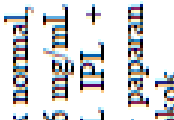

영영

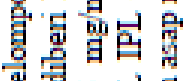

匀自

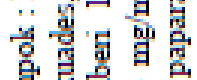

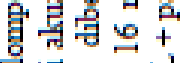

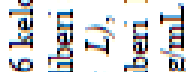

年觜

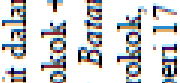

불

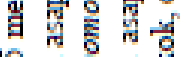

咷园园

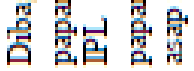

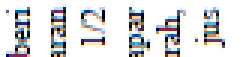

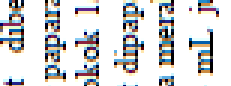

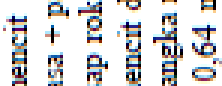

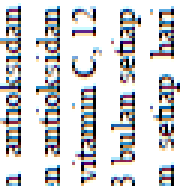

圈塄 +

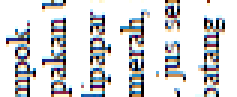

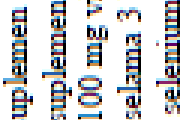

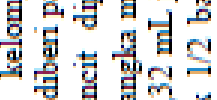

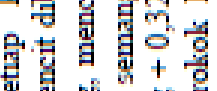

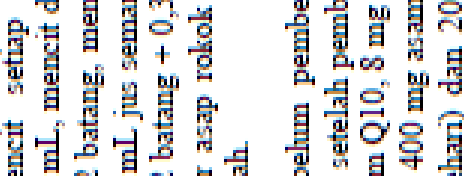

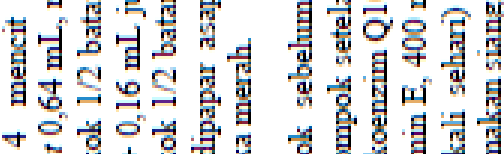

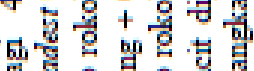

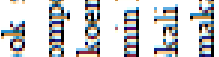

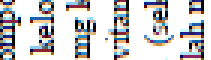

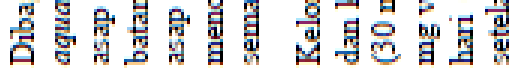

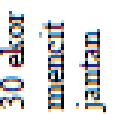

莲菁

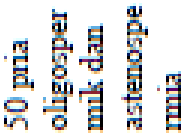
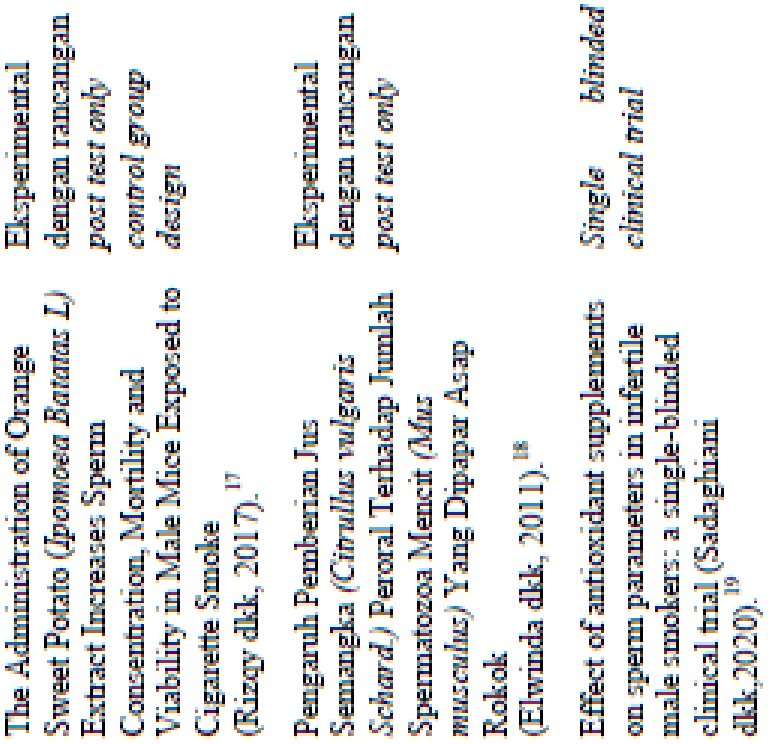
Pembentukan ROS dalam spermatozoa dapat terjadi melalui dua metode, yaitu sistem oksidasi nikotinamida adenin dinukleotida fosfat pada tingkat membran plasma sperma dan/atau reaksi reduksi nikotinamida adenin dinukleotida pada tingkat mitokondria. Mekanisme terakhir tampaknya menjadi sumber utama ROS. Mayoritas ROS yang dihasilkan dalam spermatozoa manusia adalah $\mathrm{O}_{2}^{-}$. Produk tereduksi elektron dari $\mathrm{O}_{2}{ }^{-}$bereaksi dengan dirinya sendiri melalui pelepasan elektron untuk menghasilkan $\mathrm{H}_{2} \mathrm{O}_{2}$. Dengan adanya logam transisi seperti besi dan tembaga, $\mathrm{H}_{2} \mathrm{O}_{2}$ dan $\mathrm{O}_{2}^{-}$melakukan reaksi HaberWeiss untuk menghasilkan $\mathrm{OH}^{-}$yang sangat reaktif dan destruktif. ${ }^{20}$

Dibutuhkan antioksidan untuk dapat menangkal efek dari ROS. Salah satu antioksidan yang terbukti dapat meningkatkan kualitas spermatozoa adalah vitamin C. Vitamin $\mathrm{C}$ mempunyai sifat polaritas yang tinggi karena banyak mengandung gugus hidroksil sehingga vitamin ini mudah larut dalam air, sehingga dapat langsung bereaksi dengan radikal hidroksil, superoksida, dan hidrogen peroksida. Senyawa-senyawa radikal bebas dari asap rokok yang menyebabkan kerusakan oksidatif di DNA spermatozoa akan mengalami proses reduksi dengan vitamin C. Vitamin $\mathrm{C}$ juga mempunyai peran penting dalam melindungi lipid sperma yang mudah teroksidasi dari reaksi oksidasi yang akan menurunkan kualitas spermatozoa. ${ }^{9,11,12,13}$

Vitamin C dapat bekerja secara sinergis in vivo tuntuk mengurangi kerusakan peroksidatif pada spermatozoa dengan hidrofilisitasnya. Selain itu, jika agen ini bekerja langsung pada spermatozoa untuk menghindari kerusakan oleh ROS, perbaikan kualitas spermatozoa akan cepat, asalkan vitamin $\mathrm{C}$ mendapatkan akses ke spermatozoa baik saat ejakulasi atau di dalam epididimis. ${ }^{21}$

Penelitian yang dilakukan oleh Sanggamele dkk pada tahun 2020, melaporkan bahwa pada pemberian vitamin $\mathrm{C}$ menunjukkan peningkatan yang bermakna terhadap kualitas spermatozoa. ${ }^{13}$
Penelitian lain yang dilakukan oleh Sutanto dkk pada tahun 2017, menggunakan kombinasi vitamin $\mathrm{C}$ dan $\mathrm{E}$ terhadap kualitas spermatozoa yang terpapar asap rokok. Hasilnya, didapatkan peningkatan kualitas spermatozoa secara signifikan dengan dosis yang diberikan vitamin $\mathrm{C}$ $0,045 \mathrm{mg} / \mathrm{gBB}$ dan vitamin E 0,036 $\mathrm{mg} / \mathrm{gBB} .^{15}$

Terdapat penelitian mengenai pemberian sumber makanan yang mengandung vitamin $\mathrm{C}$ terhadap kualitas spermatozoa yang terpapar asap rokok. Penelitian Rizqy dkk pada tahun 2017 dengan menggunakan umbi jalar orange sebagai intervensi, didapatkan terjadi perbaikan kualitas spermatozoa yang terpapar asap rokok. ${ }^{17}$ Penelitian yang dilakukan oleh Elwinda dkk pada tahun 2011, dengan pemberian jus semangka didapatkan terjadi peningkatan jumlah spermatozoa setelah intervensi. $^{18}$

Penelitian lain yang dilakukan oleh Sadaghiani dkk pada tahun 2020, menggunakan subjek penelitian pria tidak subur perokok. Hasil yang didapatkan setelah pemberian suplemen antioksidan (30 mg koenzim Q10, $8 \mathrm{mg}$ seng, $100 \mathrm{mg}$ vitamin $\mathrm{C}, 12 \mathrm{mg}$ vitamin $\mathrm{E}$, dan $400 \mathrm{mg}$ asam folat sekali sehari selama 3 bulan dan $200 \mathrm{mg}$ selenium setiap hari setelah makan siang), yaitu terjadi peningkatan spermatozoa setelah pemberian intervensi. ${ }^{19}$

Penelitian ini dalam bentuk literature review memiliki kelebihan dan kekurangan. Kelebihannya adalah topik penelitian yang terkait vitamin $\mathrm{C}$. Vitamin $\mathrm{C}$ atau sumber makanan yang mengandung vitamin $\mathrm{C}$ merupakan vitamin yang sudah dikenal luas di kalangan masyarakat dan sangat mudah ditemukan. Vitamin $\mathrm{C}$ yang berperan sebagai antioksidan mampu menangkal radikal bebas dari asap rokok yang menurunkan kualitas spermatozoa. Hal ini sangat baik untuk diketahui karena penurunan kualitas spermatozoa masih menjadi masalah kesehatan yang banyak ditemukan. Adapun kekurangan dari penelitian ini adalah tidak banyak penelitian pada subjek manusia. Hanya ditemukan satu penelitian yang 
menggunakan sampel manusia yang memenuhi kriteria inklusi penelitian ini. Hasil penelitian terhadap manusia, didapatkan bahwa pemberian vitamin $\mathrm{C}$ tidak berpengaruh terhadap perbaikan kualitas spermatozoa pada pria infertil dan hanya menjadi profilaksis untuk pria perokok. Belum ada penelitian-penelitian terbaru dengan menggunakan sampel manusia. Selain itu, literatur yang didapat tidak seluruhnya membahas pemberian vitamin C saja. Peneliti menambahkan sumber makanan yang mengandung vitamin $\mathrm{C}$ pada penelitian yang akan direview karena jumlah artikel yang didapat sangat terbatas.

\section{SIMPULAN}

Pemberian vitamin $\mathrm{C}$ atau sumber makanan yang mengandung vitamin $\mathrm{C}$ terbukti memberikan pengaruh dalam meningkatkan kualitas spermatozoa yang meliputi konsentrasi, morfologi, dan motilitas spermatozoa yang terpapar asap rokok.

\section{Konflik Kepentingan}

Penulis menyatakan tidak terdapat konflik kepentingan dalam studi ini.

\section{DAFTAR PUSTAKA}

1. Putra Y. Pengaruh rokok terhadap jumlah sel spermatozoa mencit jantan (Mus musculus, Strain Jepang). J Sainstek 2014;6(1):30 42.

2. Boseke MB, Engkeng S, Tucunan AA. Determinan perilaku merokok kepala keluarga di Kelurahan Woloan 1 Utara Kecamatan Tomohon Barat Kota Tomohon. J Kesmas 2019;8(7):330.

3. Mangimbulude JC, Karwur FF, Triandhini R, Fitria. Merokok dan oksidasi DNA. Sains Med 2013; 5(2):113-20.

4. Gunawan PP, Turalaki GLA, Tendean LEN. Pengaruh pemberian pasta tomat (Solanum lycopersicum) terhadap kualitas spermatozoa tikus wistar (Rattus norvegicus) yang terpapar asap rokok. eBiomedik 2017;5(2).

5. Agarwal A, Said T. Oxidative stress, DNA damage and apoptosis in male infertility: A clinical approach. BJU Int 2005;95:503-7.

6. Taha EA, Ez-Aldin AM, Sayed SK, Ghandour NM, Mostafa T. Effect of smoking on sperm vitality, DNA integrity, seminal oxidative stress, zinc in fertile men. Urology 2012;80(4):822-5.

7. Claudia V, Queljoe E, Tendean L. Perbedaan kualitas spermatozoa mencit jantan (Mus musculus L) yang diberikan vitamin c setelah pemaparan asap rokok. eBiomedik 2013;1(1): 629-34.

8. Pavlović V, Cekić S, Ranković G, Stoiljković N. Antioxidant and pro-oxidant effect of ascorbic acid. Acta Medica Medianae. 2005;44(1):65-8.

9. Putri AP. Efek vitamin c terhadap kualitas spermatozoa yang diberi paparan asap rokok. J Majority. 2015 Jan 1;4(1).

10. Batubara IV, Wantouw B, Tendean L. Pengaruh paparan asap rokok kretek terhadap kualitas spermatozoa mencit jantan (Mus musculus). J eBiomed. 2013 Mar;1(1):330-37.

11. Harahap E, Sandora N, Winarto W. Pengaruh pemberian antioksidan vitamin c dan e terhadap konsentrasi spermatozoa mencit (Mus musculus) yang dipapar asap rokok. J I Ked. 2017;5(1):26-34.

12. Sitohang AG, Wantouw B, Queljoe E. Perbedaan antara efek pemberian vitamin $\mathrm{c}$ dan vitamin e terhadap kualitas spermatozoa tikus wistar (Rattus norvegicus) jantan setelah diberi paparan asap rokok. J eBiomed. 2015 Apr 6;3(1).

13. Sanggamale IK, Rumbajan JM, Tendean LE. Perbedaan efek pemberian bawang putih (Allium sativum L.) dan vitamin c pada kualitas spermatozoa tikus wistar 
(Rattus norvegicus) yang diberi paparan asap rokok. J eBiomed. 2020 Jun;8(1):127-31.

14. Nugraheni $T$, Astirin OP, Widiyani $T$. Pengaruh vitamin $\mathrm{C}$ terhadap perbaikan spermatogenesis dan kualitas spermatozoa mencit (Mus musculus L) setelah pemberian ekstrak tembakau (Nicotiana tabacum L). Biofarmasi. 2003;1(1):13-9.

15. Sutanto EB, Nasihun TR, Isradji I, Sutanto LB. The effect of vitamin $\mathrm{C}$ and $\mathrm{E}$ combination on sperm quality and cement $8-\mathrm{OHdG}$ level of smoke exposed rats. World Nut J. 2017 Sep 6;1(1):28-3.

16. Ihsani N, Hernahadini N, Pertiwi L, NF MK, Fadhillah SN. Pengaruh pemberian air jeruk nipis (Citrus aurantifolia) terhadap konsentrasi dan motilitas spermatozoa mencit (Mus musculus) setelah terpapar asap rokok. J Ked Yarsi. 2019 May 13;27(1):035-42.

17. Rizqy LL, Nida NA, Noviana DA, Nasihun T, Widayati E. The administration of orange sweet potato (Ipomoea batatas $L$ ) extract increases sperm consentration, mortility and viability in male mice exposed to cigarette smoke. Sains Med. 2018 Jan 18;8(1):34-8.

18. Elwinda L, Amtarina R, Hamidy MY. Pengaruh pemberian jus semangka (Citrullus vulgaris schard) peroral terhadap jumlah spermatozoa mencit (Mus musculus) yang dipapar asap rokok. J I Ked. 2017 Nov 25;5(1):35-40.

19. Sadaghiani S, Fallahi S, et al. Effect of antioxidant supplements on sperm parameters in infertile male smokers: a single-blinded clinical trial. AIMS Public Heal. 2020;7(1):92-9.

20. Agarwal A, Virk G, Ong C, Plessis SS. Effect of oxidative stress on male reproduction. World $\mathrm{J}$ Mens Health. 2014;32(1):1-17.

21. Lanzafame F, La Vignera S, Vicari E, Calogero AE. Oxidative stress and medical antioxidant treatment in male infertility. Reprod Biomed Online. 2009;19(5):638-59. 